\section{Flying high}

\section{Niek van Dijk}

One of my first international lectures was in 1995 at the combined congress of the International Society of the Knee (ISK) and the International Arthroscopy Association (IAA) in Hong Kong. The meeting was held with the intention of finalising the merger of the two societies and create one strong organisation: the International Society of Arthroscopy Knee surgery and Orthopaedic Sports medicine (ISAKOS). At the time, I was working as a young registrar at Orthopaedic Department of the Academic Medical Centre in Amsterdam and my department chief was René Marti, who was ISK's president. "This is a good podium for you", he told me. He invited me to give an instructional course lecture (ICL) on ankle arthroscopy. The title of the ICL was 'Value of arthroscopy in other joints'. The other speaker in this ICL was one of the godfathers of orthopaedic sports medicine in the USA, Jimmy Andrews. I was obviously excited to be presenting together. As a fellow, I had visited Dr Andrews a few years before in Alabama. This fellowship had been instrumental for me. His skills to rotate several operating rooms simultaneously and still find the time to teach us, patiently answering all our questions, had amazed me. But most of all I still remember his energy, his generosity and overwhelming hospitality. He invited me to have dinner at his home proudly showing me his car collection before dinner. And it was not just Bentleys. Apart from the tips and tricks on anterior cruciate ligament intraarticular and extra-articular reconstructions, posterolateral and multiligament reconstructions, there was something much larger that I learnt. In Europe in those days, orthopaedics was just another specialty. But in America, it was quite simply the most prestigious discipline. It might have been the money of course, that Orthopods had the highest salaries and prestige follows the money. But there was more than that. I also observed that research in orthopaedic sports medicine was not generally academic, and did not focus on the ankle.

I returned home bubbling with excitement, and a clear idea of what I wanted to do. First, to make Dutch orthopaedics

Amsterdam UMC, University of Amsterdam, Department of Orthopaedic Surgery, Amsterdam, The Netherlands

Correspondence to Professor C Niek van Dijk, Academic Medical Center Amsterdam, Amsterdam 1105AZ, The Netherlands; C.NiekvanDijk@JISAKOS.com as prestigious as American orthopaedics, or perhaps I should say, to (try and) make Dutch orthopaedics as good as American. Second, to (try and) make orthopaedic sports medicine a proper academic discipline. And third to focus my research on ankles.

So the invitation to Hong Kong to lecture on ankle arthroscopy was a great opportunity for me. And what a prospect it was to lecture with one of my peers. But fate intervened, as it often does. Family reasons kept Jimmy in Alabama and he asked me to give his talk on.... elbow arthroscopy! Since that day, I have been performing elbow arthroscopy for almost 20 years. It was this aspect of learning with a broad and enlightening perspective on (new) techniques and approaches to various conditions, as well as the networking and the interaction with my peers, which made me attend all biannual ISAKOS congresses from the inaugural meeting in Buenos Aires up to the most recent in Cancun. I have not missed a single one.

I have watched the society grow over these past 25 years and it has helped me grow. Already in the summer of 2003, it was Per Renström in his presidential message who wrote 'ISAKOS is today the accepted world organisation in arthroscopy, knee surgery and orthopaedic sports medicine". 1 In those early years, the biannual congress was the main asset for the society. According to ISAKOS president Gary Poehling, the programme was 'a blending of international cultures through effective communication as well as amalgamating the interest of knee reconstructive surgeons and arthroscopic surgeons whose province extends beyond the knee' (presidential message summer $\left.1997^{1}\right)$.

In 2006, the ISAKOS winter newsletter had a section 'What are new members saying'. One such new member, Willem van der Merwe-who is now our current president-formulated the role and importance of ISAKOS in his community as follows: "By being an active member, my patients can feel comfortable that they are receiving appropriate care" 1

From the beginning, members are the main strength of the society, and Committee work is the beating heart of the society. The best experts in the world are proud to serve ISAKOS and contribute to meet the challenges in our field.
With some 3000 members coming from 97 countries and regions around the world, the international character is indeed a major strength of our society.

But this strength could also be a weakness at the same time. If we had chosen faculty members in search for a regional balance, rather than how good they were, it could have damaged the scientific program of our meetings. Indeed, it used to be said-by some-in those early days that 'ISAKOS stands for politics, whereas some of the older societies in the orthopaedic sports medicine field stand for quality'. Was this mere jealousy? Hmmm...When we consider the publication rates of abstracts from the early ISAKOS congresses (34\%), they were about half the rate of the Arthroscopy Association of North America (AANA) and the American Orthopaedic Society of Sports Medicine (AOSSM) (67\%). ${ }^{2-4}$ But wasn't this just a new association finding its way?

Roland Jakob (ISAKOS president 1999-2001) in his presidential message, reflects on the third ISAKOS congress in Montreux as follows: "Many fond memories come up: the social evening at the circus in Vevey, the boat excursion and the sound of Miles Davis during the breaks, reminding us of the Montreux jazz festival. In the end these are the moments that stay in one's memories, not just the lectures". ${ }^{1}$ And of course he had a point, the social aspect of these meetings is important, and lingers in the memory. But shouldn't the content come first?

In his presidential lecture 'ISAKOS or IKARUS', Roland Jakob cautioned us about 'flying too high'. I would like to think he had Per Ardua ad Astra in mind (through struggles to the Stars) (the motto of various air-forces in the English-speaking world). Because, despite his warning, ISAKOS really did become airborne after Montreux, and has been climbing successfully and fast. It began with a very successful Global Connection Campaign, then the educational platform Global Link, the successful teaching centre programme, OrthoEvidence, the ever expanding fellowship programme and the residency and fellowships directory. Not to forget the book publishing programme, and last but not least the launch of Journal of ISAKOS: JISAKOS.

So what about this early joke about the quality of the ISAKOS congresses? Did we come out of our teens and have we reached maturity?

In this issue of the JISAKOS, Pagni et al $l^{5}$ (Pagni PA, JISAKOS 2020 issue 5.2) analysed the publication rates following 
a podium presentation at the ISAKOS biannual congresses. Publication rates of abstracts presented at the ISAKOS congress have improved dramatically from $34 \%$ in 1997 to $55 \%$ in 2013.

Current publication rates of $55 \%$ are comparable to other orthopaedic conferences. The European Society of Sports traumatology, Knee Surgery and Arthroscopy (ESSKA) biannual congress reported publication rates in 2008 and 2010 of $52 \%$ and 59\%, respectively. The American Academy of Orthopaedic Surgery 2001 meeting had a publication rate of $49 \%$. Publication rates of abstracts presented at the annual meetings of AANA and AOSSM were notably higher at $67 \%$, but only 50-100 abstracts are presented each year which is a fraction of the 746 presented at the ISAKOS meeting. Based on these findings, it is evident that the ISAKOS Congress disseminates a wide range of knowledge to the orthopaedic community at the same rate as other prominent orthopaedic meetings but on a larger international scale.

Abstracts from the 2013 congress were published in 82 different journals, which exemplifies the international reach of the ISAKOS congress. Furthermore, the mean overall impact factor (IF) among all published articles was 3.6! This compares favourably with the mean IF of 2.3 among published abstracts following the 2008 ESSKA congress. The high mean IF for the publications which followed a podium presentation at an ISAKOS congress is a reflection of the high volume of publications in prominent high impact orthopaedic journals such as the American Journal of Sports Medicine, Knee Surgery, Sports Traumatology and Arthroscopy and the Journal of Arthroscopy.

Do we fly too high? I think not. Now celebrating its 25 th anniversary, ISAKOS is balanced through a broad international participation and involvement. The organisation is inclusive rather than exclusive. ISAKOS provides a sense of 'family' among the members and combines this with the highest scientific quality. And now we have a successful journal. All this makes us irresistible and ready for the future.

Funding The authors have not declared a specific grant for this research from any funding agency in the public, commercial or not-for-profit sectors.

Competing interests None declared.

Patient consent for publication Not required.

Provenance and peer review Commissioned; internally peer reviewed.

\section{(อ) OPEN ACCESS}

Open access This is an open access article distributed in accordance with the Creative Commons Attribution Non Commercial (CC BY-NC 4.0) license, which permits others to distribute, remix, adapt, build upon this work non-commercially, and license their derivative works on different terms, provided the original work is properly cited, an indication of whether changes were made, and the use is non-commercial. See: http:// creativecommons.org/licenses/by-nc/4.0/.

(C) International Society of Arthroscopy, Knee Surgery and Orthopaedic Sports Medicine 2020. Re-use permitted under CC BY-NC. No commercial re-use. Published by BMJ.

D Check for updates

To cite van Dijk CN. J ISAKOS 2020;5:61-62.

J ISAKOS 2020;5:61-62.

doi:10.1136/jisakos-2020-000436

\section{REFERENCES}

1 ISAKOS history (Internet) San Ramon (Ca): International Society of arthroscopy, knee surgery and orthopaedic sports medicine, 2019. Available: https://www.isakos. com/GlobalLink/Newsletter [Accessed Jan 2020].

2 Eck JC. Publication rates of Abstracts presented at biennial meetings of the International Society of arthroscopy, knee surgery and orthopaedic sports medicine. Knee Surg Sports Traumatol Arthrosc 2005;13:426-9.

3 Lehman JD, Nwachukwu BU, Ferraro R, et al. Publication rates of Podium presentation Abstracts at the arthroscopy association of North America annual meetings 2004-2012. Arthroscopy 2017;33:835-9.

4 Kinsella SD, Menge TJ, Anderson AF, et al. Publication rates of podium versus poster presentations at the American orthopaedic Society for sports medicine meetings: 2006-2010. Am J Sports Med 2015;43:1255-9.

5 Pagni BA, Middleton JA, Larson JS, et al. Increase in publication rates and publicationbias found following presentation at thelnternational Society of Arthroscopy, KneeSurgery, and Orthopaedic Sports Medicine (ISAKOS) biennial congress. JISAKOS 2020;5:63-8. 